\title{
Genç Erişkin Erkeklerde Şiddet Eğilimi ve Psikolojik Durum ile İlişkisi
}

\author{
Violence Tendency on Male Adolescents and the Relations with Their \\ Psychological Status
}

\author{
Özge Iş1l ÇETİN ${ }^{1}$, Semra ERDOĞAN²
}

İletişim/ Correspondence: Özge Iş1 ÇETíN Adres/Adress: Konya Askeri Hastanesi, Şeyhsadrettin Mah. Meram/ Konya, Tel: 03323212041 E-mail: isil_ozge_izmir@hotmail.com

\section{$\ddot{O} Z$}

Amaç: Bu araştırma, genç erkek erişkinlerin şiddete eğilim düzeylerini tanımlamak, sosyo-demografik ve psikolojik özellikleri ile ilişsisini ve etkileyen faktörleri ortaya koymak amacıyla tanımlayıct-iliş̧ki arayıcı tipte planlanmıştır.

Yöntem: Araştırmanın örneklemini, Konya ilinde Mayls-Aralık 2015 tarihleri arasında askeri hastaneye başvuran 200 genç erişkin oluşturmuştur. Veriler "Soru Formu”, "Şiddet Eğilim Ölçeği (ŞEÖ)”, "Kisa Semptom Envanteri-(KSE)-(Brief Symptom Inventory-(BSI)" kullanılarak toplanmıştır. Verilerin analizi için bağımsız örneklem t testi, varyans analizi ve çoklu doğrusal regresyon analizi kullanılmıştır.

Bulgular: ŞEÖ ve KSE arasında güçlü ilişkiler bulunmuştur. Regresyon Analizine göre, şiddete eğilim modelinde sırasıyla kardeş saylsl, önceden şiddete maruz kalma, psikolojik hastalı öyküsü, alkol kullanma öyküsü ve sağllk algısı şiddet eğilimini açıllayan en güçlü faktörler olarak bulunmuştur.

Sonuç: Bulgular Türkiye'nin farklı bölgelerinden gelen ve bir askeri birlikte toplanan gençlerin şiddet davranışlarını yansitmıştır. Sonuçlar, genç erkeklerin toplu olarak yaşadlğı kurumlarda (askeri birlikler, yurtlar, yatıll okullar vb.) planlanacak eğitim ve danışmanlık programlarında yol gösterici olarak kullanılabilir.

Anahtar Kelimeler: Şiddet, genç erişkin, şiddet ĕgilimi, Kısa Semptom Envanteri.

\section{ABSTRACT}

Aim: This research was designed in descriptive-correlational in order to determine the level of violence, socio-demographic and psychological characteristics and factors affecting the relationship among young adult men.

Method: The sample of this study was composed of 200 young adult men admitted to Konya Military Hospital between MayDecember 2015 period. The research data were gathered by using "Questionnaire", "Violence Tendency Scale (VTS)", "Brief Symptom Inventory (BSI)". Independent samples t-test, ANOVA and multiple linear regression analysis were used for the evaluation of the data.

Results: It was found strong relations between VTS and BSI. According to regression model, the number of siblings, violence exposure, psychological disorders, using alcohol and health perception were strongly found out in a positive way in violence tendency model.

Conclusion: This study's findings were reflected the violent behavior of military soldiers gathered from different regions in Turkey. The results can be used as a guide to planning education and counseling program among male adolescents living in places such as military units, dormitories, boarding schools, etc.

Keywords: Violence, young adult men, violence tendency, Brief Symptom Inventory.

İstanbul Üniversitesi Sağllk Bilimleri Enstitüsü Yüksek Lisans Tezi 2016, ${ }^{1}$ Hemşire Konya Asker Hastanesi, Konya/ TURKEY, ${ }^{2}$ Prof. Dr. İstanbul Üniversitesi Florence Nightingale Hemşirelik Fakültesi, İstanbul/ TURKEY

Yazının gönderilme tarihi: 18.07.2016

Yazının basım için kabul tarihi: 02.06.2017

doi: $10.17672 /$ fnhd.76693 


\section{GíRiş}

Şiddet olgusu insanlık tarihi kadar eski, ancak modern dünyanın üstesinden gelmekte başarısız olduğu bireysel ve sosyal bir gerçektir. Şiddet, her geçen gün farklı şekillerde, farklı anlamlarda yaşamı tehdit etmektedir. Günümüzde, bireysel ve toplumsal sorunların başında gelen şiddeti kontrol etmek, yaşamı bu girdaptan kurtarabilmek için öncelikle şiddetin anlamlandırılması ve etki eden faktörlerin belirlenmesi gerekmektedir (Gençoğlu, Kumcağız ve Ersanlı 2014; Özgür, Yörükoğlu ve Arabacı 2011).

Dünya Sağlık Örgütü, şiddeti "bireyin kendisine, diğer bir kişiye ya da gurup veya topluluğa kasıtlı olarak fiziksel güç ya da kudret uygulanması ya da bununla tehdit edilmesi" olarak tanımlamıştır (WHO 2014). Kendine yöneltilmiş şiddet; intihara yönelik düşünceler, intihar girişimleri, kendini yaralama, ihmal vb. davranışları içerir. Kişiler arası şiddet; çocuk istismarı, eş şiddeti ve yaşlı istismarı gibi davranışları; kollektif şiddet ise organize guruplarca yapılan nefret suçlarını, terörist saldırıları ve suç örgütlerince yapılan şiddeti tanımlar (Gençoğlu ve ark. 2014; TBMM Araştırması Komisyonu 2007).

Şiddete eğilim ve ortaya çıkma nedenleri ile ilişkili birçok etkenden söz edilmektedir. Haskan-Avcı ve Yıldırım (2014)'a göre, şiddetin oluşumunda rol oynayan önemli faktörler, sosyal, kültürel ve ekonomik nedenlere bağlıdır. Bir toplumda hangi davranışın şiddet olarak nitelendirileceği o toplumun kültürel yap1sına ve değer yargılarına göre belirlenmektedir. Şiddet ekolojik ilişki çerçevesinde değerlendirildiğinde, her bireyin içerisinde bulunduğu bireysel, ailevi, çevresel ve toplumsal özellikler ön plana çıkmaktadır (Gençoğlu ve ark. 2014).

Bireysel faktörler, psikiyatrik hastalık öyküsü, tahrik edilme, engellenme, güç ve kontrol sağlama, bağımlı/ muhtaç olma, iletişim ve çatışma çözme becerilerinin öğrenilmemesi ile ilişkilendirilirken; ailevi faktörler arasında, aile içi iletişim ve etkileşim, ailede yaşanan çatışma ve tutarsız disiplin uygulamaları önemli etkenler olarak sayılmaktadır (Anderson ve Bushman 2002;
Özgür ve ark. 2011; Zinnur-Kılıç 2012). Çevresel ve toplumsal faktörler olarak, medya ve toplumun şiddete karşı duyarlılı̆̆ı, şiddet araçlarına kolay ulaşım, eğitimin niteliğinde yetersizlikler, şiddetin toplumda hoş görülmesi, sorun çözme yöntemi olarak görülmesi, medyanın etkisi, cinsiyet rolleri, yaşam sıkıntıları, göçler ve küreselleşme tanımlanmıştır (Gençoğlu ve ark. 2014; Ögel, Tarı ve Yılmazçetin-Eke 2006).

Şiddet sonucu etkilenen dezavantajlı gruplar arasında gençler ve erkekler önemli yer tutmaktadır. Gençlerin neden olduğu şiddet, toplumda en çok göz önünde olan şiddet biçimlerinden biridir (Avcı ve Güçray 2010; Haskan-Avc1 ve Yıldırım 2014; Türküm 2011; Zinnur-Kılıç 2012). Nedenleri büyük oranda, gençlerin şiddet içeren ortamda daha fazla bulunması, maruz kalması ve sorunlarını şiddet olmaksızın çözmede zorlanması olarak açıklanmıştır (Türküm 2011).

Türkiye İstatistik Kurumu (TÜİK 2014) verilerine göre; Türkiye'de 15-29 yaş grubu oranı \%24.8 iken örneğin Orta Avrupa ülkelerinde ortalama genç nüfus oranı \%11'dir (TÜİK 2014). Ülkemizdeki bu orana Türkiye'nin yakın dönemde aldığı göçler de eklenirse, şiddete eğilim yönünden risk taşıyan genç nüfusun artabileceği düşünülebilir. Diğer taraftan TÜİK Gençlik İstatistikleri (2014) verilerine göre, yetişkin erkekler arasında birini öldürme suçu \%3.9 iken, bu oran genç erkeklerde \%4.6'dır.

Şiddet, nedenleri ve sonuçları ile günümüzün önemli bir halk sağlığı sorunu olmuştur. Şiddete eğilimli birçok birey giderek potansiyel tehdit oluşturmakta ve artan şiddet bireylerin ve toplumun biyolojik, fiziksel ve sosyal iyilik halini bozmaktadır. Şiddetin azaltılmasında, şiddete müdahale kadar önleyici girişimler de önemlidir. Şiddeti önleyebilmek ise, risk etkenlerinin ve ilişkili faktörlerin bilinmesini gerektirir.

$\mathrm{Bu}$ araştırmada genç erkeklerin şiddete eğilim düzeylerini tanımlamak, şiddet eğilimine neden olan etkenler ve ilişkili faktörler hakkında bilgi sağlayarak şiddeti önleyen eğitim ve danışmanlık programlarına katkı sağlamak amaçlanmıştır. Verilerin askerlik görevini yapmak üzere Türkiye'nin farklı bölgelerinden 
gelen gençlerden toplanması, araştırma sonuçlarının bir Türkiye mozaiği için temel oluşturması yönünden bilgi sağlayacağı düşünülmüştür.

\section{YÖNTEM}

\section{Araştırmanın Tipi}

$\mathrm{Bu}$ araştırma tanımlayıcı-ilişki arayıcı tipte planlandı.

\section{Araştırmanın Evreni ve Örneklemi}

Bu çalışmanın evrenini, Mayıs-Aralık 2015 tarihleri arasında Konya ilinde, askerliğe yeni başlayan genç erkekler oluşturdu (N:1348). Örneklem hacmi \%5 anlamlılık düzeyinde, N: 196 olarak belirlendi. Çalışmanın örneklemini, askerliğe kabul muayenesi nedeniyle Konya Asker Hastanesi'ne başvuran, araştırmaya gönüllü olarak katılan, herhangi bir sağlık sorunu olmayan, iletişim kurabilen, Türkçe okuyup yazabilen 200 genç erkek oluşturdu.

\section{Veri Toplama Araçları ve Verilerin Toplanması}

Gençlere çalışma hakkında bilgi verildikten sonra anket formları araştırmacının gözetiminde uygulandı. Anketlerin doldurulması her bir kişi için ortalama 15$20 \mathrm{dk}$ sürdü. Verilerin toplanmasında "Soru Formu", "Şiddet Eğilim Ölçeği (ŞEÖ)" ve "Kısa Semptom Envanteri- (KSE) (Brief Symptom Inventory-BSI)" kullanıld1.

Soru Formu: Soru formu, araştırmacılar tarafindan şiddet eğilimi ile ilgili kaynaklar incelenerek hazırland. Bu form gençlerin sosyo-demografik özellikleri, alışkanlıkları, psikolojik hastalık öyküsü, sağlık alg1s1 ve şiddete maruziyeti ile ilişkili toplam 22 soruyu içerdi.

Şiddet Eğilim Ölçeği (ŞEÖ): Bu ölçek, Göka, Bayat ve Türkçapar (1995) tarafından Milli Eğitim Bakanlığ 1 adına yapılan bir araştırmada, "Ortaöğrenim öğrencilerinin şiddet eğilimlerini ölçmek için geliştirilmiştir. Daha sonra, ölçeğin temel yapısı yeniden desenlenmiş ve kapsam geçerliği sağlanarak, T.C. Başbakanlık Aile Araştırma Kurumu'nun “Aile İçinde ve Toplumsal Alanda Şiddet”" (1998) konulu araştırmasında ve yanı sıra diğer araştırmalarda (Özgür ve ark. 2011; Uysal ve Bayık-Temel 2009) kullanılmıştır. Ölçeğin güvenirlik katsayısı iki farklı zamanda, .78 ve .87 bulunmuştur (T.C. Başbakanlık Aile Araştırma Kurumu 1998). Bu çalışmada, aynı ölçeğin Cronbach Alfa değeri, .86'dır. Ölçekteki 20 soru dörtlü Likert tipi (1) "hiç uygun değil” den, (4) “çok uygun”a değişen puanlama yapılarak kullanılır. Ölçeğin puan aralığı min: 20-max: 80 olarak hesaplanır. Şiddet eğilim düzeyleri; 21-40 puan: düşük, 41-60 puan: orta ve 61-80 puan: yüksek olarak değerlendirilir.

\section{Kisa Semptom Envanteri-KSE (Brief Symptom} Inventory-BSI): Kisa Semptom Envanteri-KSE, Derogatis (1992) tarafından geliştirilmiştir. Bu aracın orijinal yapısı 9 alt ölçek, ek maddeler ve 3 global indeks olmak üzere, toplam 90 maddeden oluşur. Ölçeğin Türkçe geçerlik ve güvenirlik çalışması Şahin ve Durak (1994) tarafindan yapılmıştır. Türkçe Formun 5 alt boyutu ve toplam 53 maddesi vardır. Öz-değerlendirme türünde bir envanterdir. Dörtlü Likert tipteki bu ölçeğin puan aralığı min: min: 0-max: 212 'dir. Ölçekten alınan toplam puanların yüksekliği, bireyin semptomlarının sıklığını gösterir. Bu çalışmada KSE'nin Cronbach Alfa güvenirlik katsayıs1 .95 bulunmuştur. Kısa Semptom Envanteri'nin 5 alt ölçeği bulunmaktadır.

Anksiyete: Korku, endişe, gerginlik, sinirlilik, titreme, paniğe kapılma, bulantı, diyare, idrar sıklığı, nefes alamama hissi, terleme, s1k s1k nefes alma gibi semptom ve davranışları içerir. Anksiyete alt ölçeği 13 maddeden oluşur.

Depresyon: Keder, karamsarlık, kötümserlik, mutsuzluk, yalnızlık, benliğe ilişkin olumsuz duygular, intihar eğilimi, ilgi kaybı ve kararsızlık gibi semptom ve davranışları içerir. Depresyon alt ölçeği 12 maddeden oluşur.

Olumsuz Benlik: Bireyin kendini başkalarıyla karş1laştırdığında kişisel yetersizlik ve küçüklük duygularına kapılarak kendini küçük, başarısız, değersiz görme ve suçluluk duyguları gibi semptomları içerir. Olumsuz Benlik alt ölçeği 12 maddeden oluşur. 
Somatizasyon: Herhangi bir fizik bozukluk nedeniyle olmadığı anlaşılan, yıllarca devam eden, tekrarlayıcı birçok somatik şikayetleri içerir. Somatizasyon, bayılma, göğüs ağrıları, karın ağrısı, bulantı, nefes darlığı, bedende uyuşmalar gibi belirtileri kapsar. Somatizasyon alt ölçeği 9 maddeden oluşur.

Hostilite: Sinirlilik ve titreme hali, öfkelenme, kızma, güvensizlik, birini dövme, yaralama ve zarar verme isteği, bir şeyleri kırma dökme isteği gibi semptomları içerir. Hostilite alt ölçeği 7 maddeden oluşur.

\section{Araştırmanın Etik Yönü}

Araştırma öncesi, Gata Etik Kurulu'ndan ve anketleri uygulamak için Gata Anket Kurulu'ndan onay alındı. Anketler, araştırmaya katılmayı kabul eden gönüllülerden imzalı "Bilgilendirilmiş gönüllü olur" belgesi alındiktan sonra uygulandi.

\section{Araştırmanın Değerlendirilmesi}

Çalışmanın verilerinin değerlendirilmesi SPSS 15.0 istatistik programı kullanılarak yapıldı. Çalışmanın verilerini değerlendirmek için tanımlayıcı istatistik yöntemleri (frekans, yüzde, ortalama ve standart sapma); gruplar arasındaki farkın test edilmesi için bağımsız örneklem $t$ testi ve varyans analizi; gruplar arasındaki farklılıkları saptamak için Tukey istatistiği; sürekli değişkenler arasındaki ilişki düzeyi için Pearson korelasyon testi kullanıldı. Ayrıca, şiddete eğilimi etkileyen bağımsız faktörlerin belirlenmesi için çoklu regresyon analizinden yararlanıldı. Sonuçlar \%95 güven aralığında, anlamlılık ise $\mathrm{p}<0.05$ altında değerlendirildi.

\section{BULGULAR}

Araştırmaya katılan 200 genç erkeğin yaş ortalaması 22.09 $\pm 2.34, \% 80$ 'i (n:60) bekar; \%73.5'i (n:147) ilk ve ortaokul mezunu, \%61'i (n:122) en fazla 3 kardeşli, \%72'si (n:144) bir işte çalışan ve \%97'si (n:194) düşük ve orta gelirli gençler idi. Genç erkeklerin \%19'u (n:38) daha önce psikolojik bir sorun yaşadığını,
\%18.5' i (n:37) ailede psikolojik hastalık öyküsü olduğunu, \%27.5'i (n:55) şiddete maruz kaldığını, \%69.5'i (n:139) sigara, \%35'i (n:70) alkol ve \%6.5'i (n:13) madde kullandığını belirtti.

Tablo 1'de katılımcıların şiddete eğilim düzeylerine göre dağılımı gösterilmiştir. Gençlerin şiddete eğilim puan ortalamas $41.66 \pm 11.31$ (min-max $=23-75)$ idi. Şiddete eğilim düzeyleri katılanların \%53'ünde "düşük” (21-40 puan), \%40.5'inde “orta” (41-60 puan),\% 6.5 'inde ise "yüksek" (61-80 puan) bulundu. Özetle, gençlerin yaklaşık yarısının (\%47) şiddet eğilim düzeyleri “orta/yüksek" olarak değerlendirildi.

Tablo 1. Genç Erişkin Erkeklerin Şiddete Eğilim Düzeylerine Göre Dağılımı

\begin{tabular}{|l|c|c|c|c|}
\hline $\begin{array}{l}\text { Şiddet Ĕgilim } \\
\text { Ölçeği }\end{array}$ & $\mathbf{n}$ & $\mathbf{\%}$ & Ort \pm SD & (min-max) \\
\hline Düşük $(21-40$ p) & 106 & 53.0 & $32.94 \pm 5.03$ & $23-40$ \\
\hline Orta (41-60 p) & 81 & 40.5 & $49.02 \pm 5.28$ & $41-60$ \\
\hline Yüksek (61-80 p) & 13 & 6.5 & $65.57 \pm 4.47$ & $61-75$ \\
\hline
\end{tabular}

Genç erkeklerin sosyo-demografik özelliklerine göre şiddet eğilim düzeyleri Tablo 2'de gösterilmiştir. Örneklemin şiddet eğilimleri eğitim durumu ve kardeş sayısına göre değişti. Orta öğretimli gençlerin şiddete eğilim puan ortalaması, üniversite ve üstü olanlara göre yüksek $(\mathrm{p}<0.05)$; kardeş sayısı 4 ve üstü olanların, 3 ve altı olanlara göre yüksek $(p<0.05)$ bulundu. Medeni durum (evli-bekar) ve çalışma durumuna (çalışıyor-çalışmıyor) göre gençlerin şiddete eğilim düzeyleri değişmedi. Buna karşın, sağlık güvencesi olmayanların şiddet eğilimi ortalaması, olanlara göre yüksek bulundu $(\mathrm{p}<0.05)$.

Kendilerinde ve ailelerinde psikolojik hastalık öyküsü olan gençlerin şiddete eğilim puan ortalaması, öyküsü olmayanlara göre yüksek bulundu (sırasıyla, $\mathrm{p}=.005$ ve $\mathrm{p}=.019)$. Ayrıca, daha önce şiddete maruz kalan ve madde kullanma öyküsü olanların şiddete eğilim puan ortalaması, olmayanlara göre anlamlı olarak yüksek idi $(\mathrm{p}<0.01)$ (Tablo 2). 
Tablo 2. Genç Erişkin Erkeklerin Sosyo-Demografik Özelliklerine Göre Şiddete Eğilimleri

\begin{tabular}{|c|c|c|c|c|c|c|c|}
\hline \multirow{2}{*}{\multicolumn{3}{|c|}{ Demografik Özellikler }} & \multicolumn{2}{|c|}{ Şiddet Eğilimi } & \multicolumn{3}{|c|}{ İstatistik } \\
\hline & & & \multirow{2}{*}{$\begin{array}{c}\mathbf{n} \\
23\end{array}$} & \multirow{2}{*}{$\frac{\mathbf{X} \pm \text { SD }}{43.17 \pm 10.69}$} & $\mathbf{F}$ & $\mathbf{P}$ & Tukey \\
\hline \multirow{3}{*}{\multicolumn{2}{|c|}{ Eğitim Durumu }} & İlköğretim ${ }^{\text {a }}$ & & & \multirow{3}{*}{5.058} & \multirow{3}{*}{$.007 *$} & \multirow{3}{*}{$b>c$} \\
\hline & & Orta öğretim ${ }^{b}$ & 124 & $43.15 \pm 12.12$ & & & \\
\hline & & Üniversite ve üstüc & 53 & $37.50 \pm 8.31$ & & & \\
\hline \multirow{2}{*}{\multicolumn{2}{|c|}{ Medeni Durum }} & Evli & 40 & $41.92 \pm 9.65$ & \multirow{2}{*}{0,165} & \multirow{2}{*}{0,869} & \\
\hline & & Bekâr & 160 & $41.59 \pm 11.7$ & & & \\
\hline \multirow{2}{*}{\multicolumn{2}{|c|}{ Çalışma Durumu }} & Çalışıyor & 144 & $41.55 \pm 10.83$ & \multirow{2}{*}{-0.339} & \multirow{2}{*}{0.735} & \\
\hline & & Çalışmıyor & 55 & $42.16 \pm 12.53$ & & & \\
\hline \multirow{2}{*}{\multicolumn{2}{|c|}{ Sağlık Güvencesi }} & Var & 120 & $39.96 \pm 10.61$ & \multirow{2}{*}{-2.633} & \multirow{2}{*}{$.009 *$} & \\
\hline & & Yok & 80 & $44.2 \pm 11.88$ & & & \\
\hline \multirow{2}{*}{\multicolumn{2}{|c|}{ Kardeş Sayısı }} & 3 ve alta ${ }^{a}$ & 122 & $38.95 \pm 7.68$ & \multirow{2}{*}{3.798} & \multirow{2}{*}{$.011 *$} & \multirow{2}{*}{$\mathrm{b}>\mathrm{a}$} \\
\hline & & 4 ve üstü ${ }^{b}$ & 78 & $45.35 \pm 12.16$ & & & \\
\hline \multirow{2}{*}{\multicolumn{2}{|c|}{ Psikolojik Hastalık Öyküsü }} & Evet & 37 & $46.21 \pm 10.56$ & \multirow{2}{*}{2.827} & \multirow{2}{*}{$.005 *$} & \multirow{2}{*}{-} \\
\hline & & Hayır & 162 & $40.51 \pm 11.18$ & & & \\
\hline \multirow{2}{*}{\multicolumn{2}{|c|}{ Ailede Psikolojik Hastalık Öyküsü }} & Evet & 37 & $45.56 \pm 11.18$ & \multirow{2}{*}{2.355} & \multirow{2}{*}{$.019 *$} & \multirow{2}{*}{-} \\
\hline & & Hayır & 163 & $40.77 \pm 11.17$ & & & \\
\hline Siddeto & & Evet & 55 & $47 \pm 10.59$ & 420 & $000 *$ & \\
\hline ŞIddete & & Hayır & 145 & $39.63 \pm 10.93$ & 4.29 & $.000^{*}$ & \\
\hline & & Evet & 139 & $43.41 \pm 11.29$ & 0076 & $001 *$ & \\
\hline & Sigara & Hayır & 61 & $37.67 \pm 10.35$ & 0.076 & $.001 \%$ & \\
\hline 응 & Hlyl & Evet & 70 & $45.22 \pm 11.82$ & 3347 & $001 \%$ & \\
\hline$\sum^{\bar{J}} \overline{\bar{\Xi}}$ & AlkoI & Hayır & 129 & $39.73 \pm 10.61$ & $3.34 /$ & $.001^{*}$ & \\
\hline & & Evet & 12 & $51.08 \pm 15.08$ & & & \\
\hline & Diğer & Hayır & 186 & $41.01 \pm 10.77$ & 3.056 & $.003^{*}$ & \\
\hline
\end{tabular}

$*(\mathrm{p}<0.05)$

$\mathrm{Bu}$ çalışmada, genç erkeklerin şiddet eğilimleri ile Kısa Semptom Envanteri alt ölçekleri ve diğer bağıms1z değişkenler arasındaki ilişkisi incelendi ve tüm bağımsız değişkenlerin şiddet eğilimi üzerine etkisi çoklu regresyon analizi ile değerlendirildi (Tablo 3).

Gençlerin şiddet eğilim ölçeği puan skorları ile Anksiyete $(\mathrm{r}=0.552 ; \mathrm{p}=0.000)$, Depresyon $(\mathrm{r}=0.494$; $\mathrm{p}=0.000)$, Olumsuz benlik $(\mathrm{r}=0.457 ; \mathrm{p}=0.000)$, Somatizasyon $(\mathrm{r}=0.531 ; \mathrm{p}=0.000)$, Hostilite $(\mathrm{r}=0.517$; $\mathrm{p}=0.000)$ düzeyleri arasında pozitif yönde anlamlı ilişki bulundu. Şiddet eğilimi arttıkça psikopatolojik belirtiler de artt1. En yüksek ilişki ŞEÖ toplam skoru ile anksiyete arasinda bulundu $(\mathrm{r}=0.552 ; \mathrm{p}=0.000)$.
Şiddet eğilim düzeyi ile sağlık algısı arasında ise negatif yönde ilişki saptandı( $\mathrm{r}=-0.360, \mathrm{p}=0.000)$. Şiddet eğilimi arttıkça sağlık algısı azaldı. Sağlık algıları azaldıkça, Anksiyete $(\mathrm{r}=-0.440 ; \mathrm{p}=0.000)$, Depresyon $(\mathrm{r}=-0.438$; $\mathrm{p}=0.000)$, Olumsuz benlik $(\mathrm{r}=-0.453$; $\mathrm{p}=0.000)$, Somatizasyon $(\mathrm{r}=-0.471 ; \mathrm{p}=0.000)$ ve Hostilite $(r=-0.454 ; p=0.000)$ puan ortalamaları artt1.

\section{Çoklu Regresyon: Tüm Bağımsız Değişkenlerin Şiddet Eğilimi Üzerine Etkisi}

Model, katılımcıların şiddet eğilimi; yaş, medeni durum, birlikte yaşadığı kişi sayısı, kardeş sayısı, eğitim durumu, meslek grupları, kendilerinde ve ailede 
psikolojik hastalık öyküsü, şiddete maruz kalma, sigara, alkol, madde kullanma, sağlık algısı, anksiyete, depresyon, olumsuz benlik, somatizasyon ve hostilite değişkenlerini \%30.5 düzeyinde açıkladı. Kurulan model istatistiksel olarak anlamlı bulundu $\left(\mathbf{R}^{2}=\mathbf{0 . 3 0 5}\right.$; $\mathbf{F}=4.405 ; p=0.000<0.005)$. Şiddet eğilim ölçeğinin regresyon modelinde "kardeş sayısı", "psikolojik hastalık öyküsü”, "şiddete maruz kalma”, "alkol kullanma" ve "sağlık algısı" şiddet eğiliminin en güçlü açıklayıcıları olarak ortaya çıktı (Tablo 3 ).

Tablo 3. Çoklu Regresyon: Bağımsız Değişkenlerin Şiddet Eğilimi Üzerine Etkisi

\begin{tabular}{|l|c|c|c|c|}
\hline & $\mathbf{B}$ & $\boldsymbol{B e t a} \mathbf{~}$ & $\boldsymbol{t}$ & $\boldsymbol{p}$ \\
\hline (Sabit) & 65.403 & & 6.413 & $\mathbf{. 0 0 0}$ \\
\hline Yaş & -.384 & -.079 & -.971 & .333 \\
\hline Medeni durum & -2.102 & -.075 & -.797 & .427 \\
\hline Birlikte yaşadığı kişi & 1.226 & .059 & .659 & .511 \\
\hline Eğitim durumu & -1.273 & -.067 & -.849 & .397 \\
\hline Kardeş sayısı & .992 & .180 & 2.654 & $\mathbf{. 0 0 9}$ \\
\hline Meslek grupları & .720 & .128 & 1.948 & .053 \\
\hline Psikolojik hastalık & 2.084 & .151 & 2.273 & $\mathbf{. 0 2 4}$ \\
\hline Aile psikolojik hastalık & .755 & .026 & .353 & .724 \\
\hline Şiddete maruz kalma & -4.092 & -.162 & -2.193 & $\mathbf{. 0 3 0}$ \\
\hline Sigara (paket yıl) & .003 & .023 & .349 & .728 \\
\hline Alkol & -2.603 & -.151 & -2.295 & $\mathbf{. 0 2 3}$ \\
\hline Madde & -2.294 & -.104 & -1.527 & .128 \\
\hline Sağlık algılama & -1.376 & -.265 & -3.733 & $\mathbf{. 0 0 0}$ \\
\hline Anksiyete & .145 & .118 & .653 & .514 \\
\hline Depresyon & .139 & .127 & .894 & .373 \\
\hline Olumsuz benlik & -.351 & -.259 & -1.769 & .079 \\
\hline Somatizasyon & .198 & .114 & .902 & .368 \\
\hline Hostilite & .082 & .037 & .350 & .727 \\
\hline N=200; R $\mathbf{2} \mathbf{0 . 3 0 5 ; ~ F = 4 . 4 0 5 ; ~ p = 0 . 0 0 0}$ & & \\
\hline
\end{tabular}

$*(\mathrm{p}<0.05)$

\section{TARTIŞMA}

İnsan etkileşiminin tüm alanlarında yaşanan şiddet olgusu bireysel, toplumsal, kültürel ve değer yargıları ile ilişkili karmaşık bir yapı oluşturmaktadır (Kızmaz 2006; Kocacık 2001). Özellikle şiddetin genç erkeklerde sık görülmesi, toplumda şiddet üretmeleri açısından kritik bir önem taşımaktadır.
Şiddet ve saldırganlık eğilimi ile ilgili yapılan birçok çalışmada şiddet eğiliminin erkeklerde kadınlara göre daha yüksek olduğu gösterilmiştir (Balkıs, Duru ve Buluş 2005; Erdoğdu 2010; Gençoğlu ve ark. 2014; Mahlstedt ve Welsh 2005; Özgür ve ark. 2011). Bu bulgular bazı çalışmalarda, erkeklerin androjen özelliklerine sahip olması ve cinsiyetler arasındaki sosyalleşme farklılığı ile açıklanmış ise de şiddet eğiliminin cinsiyete göre değişmediğini gösteren bazı çalışmalar da bulunmaktadır (Karataş 2008; Kaura ve Lohman 2007). Bu çalışmada genç erkeklerin \%47'sinin şiddete eğilimi, orta ve yüksek düzeyde bulundu. Bu oran örneklem seçme yöntemlerine bağlı olarak değişmekle birlikte, Türkiye' de yapılan bir başka çalışmada (Özgür ve ark. 2011) bulunan orana (\%52) yakın, Kanada'lı gençlere göre (\%72) düşük bulunmuştur (Tremblay ve ark. 2004).

Bu çalışmanın bulgularına göre eğitimi daha düşük ve kardeş sayısı 4 ve üstünde olan gençlerin şiddete eğilimi daha yüksek bulundu ve fazla kardeş regresyon modeline göre de en güçlü açıklayıcılardan biri oldu. Buna karşın, gelir durumu ve yaptıkları iş ile şiddete eğilim düzeyleri arasında ilişki bulunmadı. Bu ilişkiyi inceleyen önceki araştırmalarda farklı sonuçlar rapor edilmiştir. Örneğin, Tremblay ve ark. (2004) düşük gelir düzeyi ve kardeş sayısı fazla olan gençlerin saldırganlık düzeyini daha yüksek bulurken, Karataş (2008), kardeş sayısı ve saldırganlık arasında herhangi bir ilişki rapor etmemiştir. Kaura ve Lohman (2007) ve Erdoğdu (2010) ise, şiddeti sosyoekonomik nedenler ile açıklamıştır. Bu bulgular doğrultusunda, şiddete eğilimin örneklemin özelliklerine ve şiddeti tetikleyen diğer faktörlere göre değişebileceği, ancak aile gelirinin çok kardeşe paylaştırılması sonucu sınırlı kalan bütçenin ve düşük eğitimin şiddet eğilimini tetiklediği söylenebilir.

Regresyon modeline göre, askerlerin şiddet eğilimini en güçlü açıklayan değişkenlerden ikisi, önceden şiddete maruz kalmak ve psikolojik hastalık öyküsü idi. Şiddet arttıkça ruh sağlığının bozulduğu, ruh sağlı̆̆ bozuldukça şiddet ve şiddete eğilimin arttı̆̆ bu kısır döngü, araştırma sonuçları ile de kanıtlan- 
miştır (Ayan 2007; Evren, Tokuç ve Ekuklu 2011; Gençoğlu ve ark. 2014; Güleç ve ark. 2012; Tatlılıoğlu 2013). Bu bulgu önceki çalışmalar ile uyumlu idi (Avc1 ve Gürçay 2010; Gençoğlu ve ark. 2014; Gomez 2011; Güleç ve ark. 2012; Maxwell ve Maxwell 2003). Nitekim bu çalışmada, gençlerin şiddet eğilimleri ile sağlığ 1 algılama düzeyleri arasındaki negatif anlamlı ilişki vardı. Daha da ötesi, gençlerin sağlık algısı şiddet eğiliminin en güçlü açıklayıcısı olarak bulundu. Bu bulgu, Evren ve ark. (2011)'nın işaret ettiği gibi, sağlığın kötü algılanması şiddet içeren davranışların hem belirleyicisi hem de sonucu olabilmektedir.

$\mathrm{Bu}$ çalışmada alkol, sigara ve madde kullanan askerlerin şiddete eğilimleri anlamlı olarak yüksek bulundu. Özellikle alkol, şiddet eğiliminin güçlü belirleyicisi idi. Madde kullanımı, kural tanımama ve dürtü kontrolünde azalmaya neden olmakta, bireyleri kendine ve çevreye zarar verme gibi davranışlara itmekte ve suça neden olabilmektedir. Alkol ve madde kullanımıyla, saldırganlık ve şiddet eylemlerinin birbirini tırmandırdığ 1 gösterilmiştir (Güleç ve ark. 2012; Romito ve Grassi 2007).

Bulgular, askerlerin şiddete eğilim puanları ile psikopatolojik belirtiler arasında anlamlı, güçlü ilişki olduğunu gösterdi. Bu ilişki regresyon modeline girmedi ise de, gençlerin şiddete eğilim puanları arttıkça KSE'nin 5 alt ölçeği olan "anksiyete", "depresyon", "olumsuz benlik", "somatizasyon" ve "hostilite" puanları arttı. Bu ilişki Çetin-Dağlı (2009)'nın kız ve erkek öğrencilerde yaptığı çalışmada da benzer bulundu. Kaura ve Lohman (2007)'1n, üniversite öğrencilerinde yaptığ 1 çalışmada ise, şiddete eğilim ile ilişkili bulunan belirtiler depresyon, anksiyete ve somatizasyon ile sinırlı kaldı. Bu bulgular, gençlerde şiddete eğilim ile psikopatolojik belirtiler arasında birbirini tetikleyen kısır döngüyü destekledi.

- Özetle, bu çalışma şiddete eğilimi etkileyen etki faktörlerinin gücünü ortaya koyan yönü ile önemli veri sağlamıştır. Ayrıca, örneklemin Türkiye'nin farklı bölgelerinden askeri birliğe katılan gençlerden oluşması, değişik kültürdeki genç erkeklerin şiddet eğilimlerini yansıtmıştır. Bununla birlikte çalışmada sonuçların katılımcıların bildirimi ile sinırlı olması ve olasılıksız örnekleme yöntemi kullanılması nedeniyle sonuçlar tüm gençlere genellenemez.

\section{SONUÇ VE ÖNERİLER}

Genç erkeklerin şiddete eğilim düzeyleri ile sosyodemografik ve psikolojik özellikleri arasındaki ilişkinin incelendiği bu çalışmanın sonuçlarına göre;

Şiddete eğilim düzeyi;

- Eğitim düzeyi yüksek olanlarda daha düşük, kardeş sayısı fazla ve sağlık güvencesi olmayanlarda daha yüksek idi.

- Fazla kardeş sayısı, psikolojik hastalık öyküsü, şiddete maruz kalma öyküsü, alkol kullanma ve düşük sağlık algısı şiddet eğilimini açıklayan en güçlü değişkenler olarak saptandı.

- Şiddete eğilim arttıkça psikopatolojik belirtiler de arttı. Şiddet eğilimi arttıkça sağlık algısı azaldı.

$\mathrm{Bu}$ bulgular doğrultusunda;

- Araştırmanın sonuçları, genç erkeklerin toplu olarak yaşadığı kurumlarda (askeri birlikler, yurtlar, yat1l1/gündüzlü okullar vb.) şiddetin önlenmesi konusunda planlanacak eğitim ve danışmanlık programlarına 1şık tutabilir.

- Askeri birlikte bulunan gençler için psikolojik danışma birimleri düzenli aralıklarla şiddeti önlemeye yönelik programlar düzenleyebilir.

- İleride yapılacak araştırmalarda, genç erkeklerde şiddeti etkileyen başka değişkenlerin incelenmesi önerilir.

\section{KAYNAKLAR}

Anderson, C. A., Bushman, B. J. (2002). Human aggression. Annual Review of Psychology. 53: 27-51

Avcı, R., Güçray, S. S. (2010). Şiddet davranışı gösteren ve göstermeyen ergenlerin ailelerinin aile işlevleri, öfke ve öfke ifade tarzları açısından incelenmesi. Kuram ve Uygulamada Eğitim Bilimleri, 10(1): 45-76.

Ayan, S. (2007). Aile içinde şiddete uğrayan çocukların saldırganlık eğilimleri. Anadolu Psikiyatri Dergisi, 8: 206-221. 
Balkıs, M., Duru, E., Buluş, M. (2005). Şiddete yönelik tutumların öz-yeterlilik, medya, şiddete yönelik inanç, arkadaş grubu ve okula bağl1lık duygusu ile ilişkisi. Ege Ĕgitim Dergisi, 6(2): 81-97.

Çetin-Dağlı, S. (2009). Düzce Üniversitesi Düzce Meslek Yüksekokulu öğrencilerinde şiddet sıklığının ve Kısa Semptom Envanteri'nin değerlendirilmesi. Tipta Uzmanlık Tezi, Düzce Üniversitesi Tıp Fakültesi Halk Sağlığı Anabilim Dalı, Düzce.

Erdoğdu, Y. M. (2010). Öğrencilerin saldırganlık eğilimlerinin bazı değişkenler açısından incelenmeleri. International Conference on New Trends in Education and Their Implications, 835-848.

Evren, H., Tokuç, B., Ekuklu, G. (2011). Trakya Üniversitesi öğrencilerinde şiddet davranışları ve algılanan sağlık ilişkisi. Balkan Med J, 28: 380-384.

Gençoğlu, C., Kumcağız, H., Ersanlı, K. (2014). Ergenlerin şiddet eğilimine etki eden ailevi faktörler. Turkish Studies-International Periodical for The Languages, Literature and History of Turkish or Turkic, 9(2): 639-652.

Gomez, M. A. (2011). Testing the cycle of violence hypothesis: Child abuse and adolescent dating violence as predictors of intimate partner violence in young adulthood. Youth \& Society. 43: 171-192.

Güleç, H., Topaloğlu, M., Ünsal, D. (2012). Bir kısır döngü olarak şiddet. Psikiyatride Güncel Yaklaşımlar, 4(1): 112-137.

Haskan-Avc1, Ö., Yıldırım, İ. (2014). Ergenlerde şiddet eğilimi, yalnızlık ve sosyal destek. Hacettepe Üniversitesi Ĕgitim Fakültesi Dergisi (H. U. Journal of Education), 29(1): 157-168.

Karataş, Z. (2008). Lise Öğrencilerinde Öfke ve Saldırganlık. Çukurova Üniversitesi Sosyal Bilimler Enstitüsü Dergisi, 17(3): 277 294.

Kaura, S., Lohman, B. (2007). Dating violence victimization, relationship satisfaction, mental health problems, and acceptability of violence: A comparison of men and women. Journal of Family Violence. 22(6): 367-381.

Kızmaz, Z. (2006). Şiddetin sosyo-kültürel kaynakları üzerine sosyolojik bir yaklaşım. Fırat Üniversitesi Sosyal Bilimler Dergisi, 16 (2): 247-267.

Kocacık, F. (2001). Şiddet olgusu üzerine. C.Ü. İktisadi ve İdari Bilimler Dergisi, 2(1): 1-7.

Mahlstedt, D. L., Welsh, L. A. (2005). Perceived causes of physical assault in heterosexual dating relationships. Violence Against Women, 11: 447-472.

Maxwell, C. D. Maxwell, S. R. (2003). Experiencing and witnessing familial aggression and their relationship to physically aggressive behaviors among Filipino adolescents. J Interpers Violence, 18(12): 1432-1451.
Ögel, K., Tarı, I., Yılmazçetin-Eke, C. (2006). Okullarda Suç ve Şiddeti Önleme. 1.basım, Yeniden Yayınları, İstanbul.

Özgür, G., Yörükoğlu, G., Baysan-Arabacı, L. (2011). Lise öğrencilerinin şiddet algıları, şiddet eğilim düzeyleri ve etkileyen faktörler. Psikiyatri Hemşireliği Dergisi, 2(2): 53-60.

Romito, P., Grassi, M. (2007). Does violence affect one gender more than the other? The mental health impact of violence among male and female university students. Social Science\& Medicine, 65: 1222-1234.

Tatlılıoğlu, K. (2013). Türkiye'de aile içi kadına karşı şiddetin psiko-sosyal ve kültürel dinamiklerinin değerlendirilmesi. Nişantaşı Sosyal Bilimler Dergisi, 1(1): 109-128.

Türkiye Büyük Millet Meclisi (TBMM) Araştırması Komisyonu (2007). Türkiye'de ortaöğretime devam eden öğrencilerde ve Ceza ve İnfaz Kurumları'nda bulunan tutuklu ve hükümlü çocuklarda şiddet ve bunu etkileyen etkenlerin saptanması araştırma raporu. TBMM Rehberlik ve Danışma Hizmetleri Genel Müdürlüğü, Ankara, http://www.kom.pol.tr/tubim/SiteAssets/...Raporlar/tbmm cocuk_artan.pd (3.08.2015).

T.C. Başbakanlık Aile Araştırma Kurumu (1998). Aile içinde ve toplumsal alanda şiddet, Bilim Serisi: 113, Başbakanlık Basımevi, Ankara, http://ailetoplum.aile.gov.tr/ data/54293ea2369dc32358ee2b25/kutuphane_33_aile_icinde_ve_ toplumsal_alanda_siddet.pdf (17.08.2015).

Tremblay, R. E. ve ark. (2004). Physical aggression during early childhood: Trajectories and predictors. Pediatrics, 114(1): e43-e50.

Türkiye İstatistik Kurumu (TÜİK) (2014). Nedenlerine göre ölüm istatistikleri, Ankara, http://www.tuik.gov.tr/PreHaberBultenleri. do? id=1885 (10.06.2015).

Türkiye İstatistik Kurumu (TÜİK) (2014). İstatistiklerle Gençlik, Ankara, http://www.tuik.gov.tr/Kitap.do?metod=KitapDetay\&KT ID=11\&KITAP_ID=251 (14.06.2015).

Türküm, S. (2011). Okulda şiddet: Problem çözme becerilerine ilişkin algıları ergenleri ne kadar koruyor? Kuram ve Uygulamada Eğitim Bilimleri, 11(1): 115-132.

Uysal, A., Bayık-Temel, A. (2009). Şiddet karşıtı eğitim programının öğrencilerin çatışma çözüm, şiddet eğilimi ve şiddet davranışlarına yansıması. Atatürk Üniversitesi Hemşirelik Yüksekokulu Dergisi, 12(1): 20-30.

World Health Organization (WHO) (2014). Global Status Report On Violence Prevention, http://www.who.int/violence...prevention/violence/st (16.07.2015).

Zinnur-Kılıç, E. (2012). Ergenlerde şiddet kullanımı: Bireysel ve ailesel etkenler. Nöropsikiyatri Arşivi, 49(1): 260-265. 